\title{
CONCEPTUAL MODEL FOR CLOUD COMPUTING ACCEPTANCE IN THE AUDIT PROFESSION
}

\section{KONCEPTUALNI MODEL PRIHVAĆANJA USLUŽNOG RAČUNALSTVA U REVIZORSKOJ PROFESIJI}

\author{
Dunja Dobrinić \\ Faculty of Organization and Informatics, University of Zagreb, Varaždin, Croatia \\ Fakultet organizacije i informatike, Sveučilište u Zagrebu, Varaždin, Hrvatska
}

\section{Abstract}

The paper proposes a conceptual model of cloud computing acceptance. The model includes variables from TAM (Technology Acceptance Model), TOE (Technology-organization-environment) framework, and the security risk variable. This study aims to verify the suitability of the proposed model for measuring cloud computing acceptance by the auditors and auditors' assistants in the Republic of Croatia. For the purposes of the study, data were collected through a questionnaire. The sample included 111 certified auditors and 28 auditing assistants. The structural equation modeling (SEM) method was used to analyze the data collected and evaluate the proposed model. The results confirmed the impact of perceived usefulness and time and complexity on the intention to use. The influence of image, education, perceived ease of use and security risk on perceived usefulness was confirmed, while the effect of perceived ease of use on the intention to use did not prove significant. Constructs perceived usefulness, perceived ease of use, and time and complexity explain $31 \%$ of the variance in intention to use cloud computing. The paper outlines the limitations of the research as well as the scientific contribution.

\section{Sažetak}

U radu se predlaže konceptualni model prihvaćanja uslužnog računalstva. Model uključuje varijable TAM modela, TOE okvira i varijablu sigurnosnog rizika. Cilj rada je provjeriti prikladnost predloženog modela za mjerenje prihvaćanja uslužnog računalstva od strane revizora i asistenata revizora u Republici Hrvatskoj. Za potrebe istraživanja prikupljeni su podaci putem anketnog upitnika. Uzorak je obuhvaćao 111 ovlaštenih revizora i 28 asistenata revizora. Korišteno je strukturalno modeliranje (SEM metoda) kako bi se analizirali prikupljeni podaci i procijenio predloženi model. Rezultati su potvrdili utjecaj percipirane korisnosti te vremena i kompleksnosti na namjeru korištenja. Potvrđen je utjecaj ugleda, edukacije, percipirane lakoće upotrebe i sigurnosnog rizika na percipiranu korisnost, dok se utjecaj percipirane lakoće upotrebe na namjeru korištenja nije pokazao značajnim. Konstrukti percipirana korisnost, percipirana lakoća upotrebe te vrijeme i kompleksnost objašnjavaju $31 \%$ varijance namjere korištenja uslužnog računalstva. U radu su navode ograničenja istraživanja kao i znanstveni doprinos. 


\section{INTRODUCTION}

Cloud computing is an information technology service that delivers computing services (hardware and software) over the network to customers at their request, regardless of device and location $\mathbf{1} /$. It allows to increase existing capacities and expand information technology capabilities without additional and continuous investment in new computer equipment, user training, as well as upgrade and purchase of new license $/ 2 /$. The application of cloud computing requires acceptance by the users themselves, ie individuals. The benefits of accepting cloud computing is an exhaustive research topic, due to the existence of critical factors that influence its acceptance, most of which include the individual's concern about the security and privacy of data in cloud computing /3/.

In order to identify the factors that influence the acceptance of new technologies (such as cloud computing) by individuals, several different models have been developed, such as TRA (Theory of Reasoned Action), TAM (Technology Acceptance Model). MM (Motivational Model), TPB (Planned Behaviour Theory), CTAM-TPB (Combined TAM and TPB), MPCU (PC Utilization Model), IDT (Innovation Diffusion Theory), SCT (Social Cognitive Theory), UTAUT (Unified Theory of Acceptance and Use of Technology) /4/. The literature proposes combining models that measure acceptance at the individual level with models that measure acceptance at an organizational level. It is proposed to combine individual models with a TOE framework that measures the acceptance of new information systems and technologies at the organizational level $/ 5 /, / 6 /, / 7 /$.

The paper introduces a conceptual model that combines the TAM and TOE framework with a security risk variable to investigate the attitude of auditors and audit assistants on cloud computing acceptance. Reviewing the existing research, a lack of research focused on the auditing profession and the auditors themselves has been identified, due to the usage of confidential information in their line of work and the fact that they spend most of their time outside the office. Therefore, using cloud-based applications would make their job easier. Handling confidential information makes auditors and auditors' assistants a target population to examine the impact of security risk on acceptance of cloud technology and to investigate the level of trust in cloud computing. The study aims to verify the suitability of the proposed model for measuring cloud computing acceptance by auditors and auditors' assistants.

The paper is organized as follows: In section 2, the literature review is given, in section 3 the proposed research model is explained, in section 4 the research methodology is presented. In, section 5 results and discussion are given and finally, the last section concludes with concluding remarks.

\section{LITERATURE REVIEW}

Cloud computing is defined by the National Center for the Security of National Computer Networks and Systems as "the concept of sharing a software environment that uses the Internet as a platform and allows applications and documents sent from anywhere in the world to be stored on dedicated servers" /2/. Marston and others define cloud computing as a model of information technology service in which computer services (hardware and software) are delivered to customers at their request as a form of self-service, regardless of device and location /1/. Wang and others define it as a set of online services that provide easy access to computing platforms that are personalized to the user's preferences, have appropriate levels of quality and are affordable /8/. It would be difficult to find two authors who would agree on the same definition of cloud computing. But what is certain is that everyone would agree with Marston and others that cloud computing has changed the way IT technologies are developed, used, maintained, and paid for $/ \mathbf{1} /$.

Cloud computing has enabled users to access applications anytime, anywhere, wherever they are. Cloud computing office applications are finding their place in daily business to a large extent. The use of remote server networks, instead of local servers and personal storage computers, enables the management and processing of data outside the work environment. Communication and file sharing among employees are also facilitated. The benefits of cloud computing are also the increase of existing capabilities and expansion of information 
technology capabilities without the need for additional and ongoing investment in new computer equipment, training those managing it, and upgrading and purchasing new license $/ 2 /$. To measure the acceptance of new technologies by individuals, the TAM - Technology acceptance model developed in 1989 by Fred Davis in his $\mathrm{PhD}$ thesis stands out as the leading one. It assumes that the decision to adopt a particular technology is influenced by perceived usefulness and perceived ease of use. Perceived usefulness is defined as the subjective assessment of users that using a particular technology or application system will increase their business efficiency within the organization, while perceived ease of use is defined as the perceived ease of use of new technology by the user, ie it will not take special effort (physical and mental) to learn how to use new technology or a new application system /9/.

A number of studies have used and validated the TAM to predict user acceptance of new technologies, and it has been demonstrated that perceived ease of use and perceived usefulness influence attitudes toward a particular technology, while attitudes toward technology (together with perceived utility) influence the intention to adopt new technology /10/. Over the years, the model has improved, and variables that affect the perceived usefulness and ease of use have been added. Vankattesh and Davis have identified the shortcomings of the original model in that it does not explain the reasons why users would perceive something useful and suggested additional variables for this purpose. The new model is called TAM 2, and it introduces variables that affect perceived usefulness $/ \mathbf{1 1} /$. The next model enhancement called TAM 3 was made by Vankattesh and includes variables that affect the ease of use /12/, /11/, /13/. Many researchers agree that adding additional variables to the TAM can lead to enhancing the ability of the model to measure technology acceptance. What is apparent from the literature review is that in most previous research an integrated model was used, and it included a combination of the TAM and the TOE framework. The TOE framework was developed by Tornatzky and Fleisher in 1990 /14/. The model was developed to measure the acceptance of new information systems and technologies at the organization level. It includes technological and organizational variables as well as an environmental impact. The technological variable, among others, involves complexity, while organizational variable includes training and education, as well as other factors. A disadvantage of the TOE framework is that it is too generic, so it is advised in the literature that it should be integrated with the TAM /5/, /6/, /7/. Okcu and others, in the study of the acceptance of new technology, among others include the technological complexity variable in their model /15/. Technological complexity implies the degree to which the use of new technology is perceived as relatively difficult to understand and use /16/. Complexity is introduced as a variable by both Alshamaila and Papagoannidis to measure cloud computing acceptance /8/. Unlike Okcu and others, they have confirmed the impact of complexity on the adoption of new technology.

The role of training and education has proved to be significant in accepting new technology $/ \mathbf{1 7}, / \mathbf{1 8} /$. In a study of cloud computing acceptance, Gangwar and others believe that providing employees with education and training about cloud computing will reduce anxiety and stress about using it, and at the same time act motivational on users /5/. Research has confirmed the impact of training and education on the adoption of cloud computing.

In their research, $\mathrm{Wu}$ and Wang combine the TAM with IDT, (Innovation diffusion theory), and BI (Behavioural decision theory). They extend the model with the compatibility variable from IDT and the perceived risk and cost from BDT /19/. Perceived risk refers to an individual's subjective assessment that the use of new technology will cause certain risks. Perceived risk is also included in Lee's research regarding cloud computing acceptance. They examine cloud computing acceptance from a risk perspective by looking at how much perceived risk influences the acceptance of new technology /20/. One of the risk components is security risk, which occupies a major role in the acceptance of new technology. In the context of cloud computing, this includes data security, data recovery and data leaking. Security risk also involves storing sensitive information in unknown and remote locations $/ \mathbf{2 0} /, / \mathbf{2 1} /$. An important risk is 
the time risk associated with spending time finding the right solution, buying new technology, and time spent on educating and training to work with new technology /20/. Research findings indicated that security risk had a significant impact on the adoption of new technology but the impact of the time was not proved to be significant. In research done by Park and Kim, the security risk was also found to have a significant influence on the acceptance of new technologies. They defined security risk as the level of confidence of individuals in the safety of using new technology /22/. The Curtis and Payne research agrees with the same, showing that individuals who are more risk-averse are more likely to embrace new technologies than those who are more cautious about risk. /23/ Although some authors believe that instruments such as SLA (Service Level Agreement) and TVEM (Trusted Virtual Environment Module) are sufficient to nullify risk and increase confidence levels, most authors agree that they are still not sufficient in terms of an individual's security risk perception $/ 3 /, / 24 /$.

From the literature review it is evident that most researchers agree that intention to use is sufficient indicator for the use and for the acceptance of new technology, and for that reason they eliminate the variable related to the use itself from their models $/ \mathbf{1 5} /, / \mathbf{2 2} /, / \mathbf{5} /$. The individual's intention to use the new technology indicates that the individual will use the same $/ 25 /, / 26 /$.

In order to develop a conceptual model for cloud computing acceptance for the purposes of this research, the TAM and TOE model variables were integrated and the security risk variable was added.

\section{THE PROPOSED RESEARCH MODEL}

In this section, the key variables for cloud computing acceptance were selected, and a conceptual model and associated hypotheses $(\mathrm{H})$ were given.

\subsection{Perceived usefulness (PU)}

Perceived usefulness (PU) implies a subjective assessment by an individual that the use of cloud computing will contribute to better execution of his or her tasks, that is, to improve his or her performance within the organization in which he or she works $/ 9 /$.
H1 Perceived usefulness is positively related with intention to use cloud computing.

\subsection{Image (IM)}

The use of cloud computing improves the image and status of an individual in his or her society or environment $/ \mathbf{1 1} /$.

H2 Image is positively related to perceived usefulness.

\subsection{Perceived ease of use (PEU)}

An individual's subjective assessment that the use of cloud computing will not require additional physical and mental effort $/ \mathbf{9} /, / \mathbf{1 1} /$.

H3 Perceived ease of use is positively related to perceived usefulness.

H4 Perceived ease of use is positively related with intention to use cloud computing.

\subsection{Time and complexity (TC)}

Time and complexity refer to an individual's subjective assessment that learning how to use cloud computing will take too much time and will be relatively difficult. The application of cloud computing will be more complex for users than the use of technology utilized for the same task currently used for the job $/ \mathbf{2 0} /, / \mathbf{1 5} /$.

H5 Time and complexity is negatively related to perceived ease of use.

H6 Time and complexity is negatively related with intention to use cloud computing.

\subsection{Education (ED)}

Education is an individual's subjective assessment that cloud computing acceptance would be easier if assured education and training in using cloud computing are offered prior to using it $/ 5 /$.

H7 Education is positively related to perceived usefulness.

\subsection{Security Risk (SR)}

Security risk involves an individual's concern about the security and privacy of data in cloud computing. It implies an individual's level of trust in data security when using cloud computing /22/, /19/. According to a survey from 2016 by Harvey Nash / KPMG CIO Survey "The Creative CIO", as many as $49 \%$ of IT professionals agree that the most significant obstacles for accepting cloud computing are data security and data loss $/ 27 /$.

H8 Security risk is negatively related to perceived usefulness. 
The proposed research model is shown below

(Figure 1). The model was evaluated in order to

test the hypotheses.

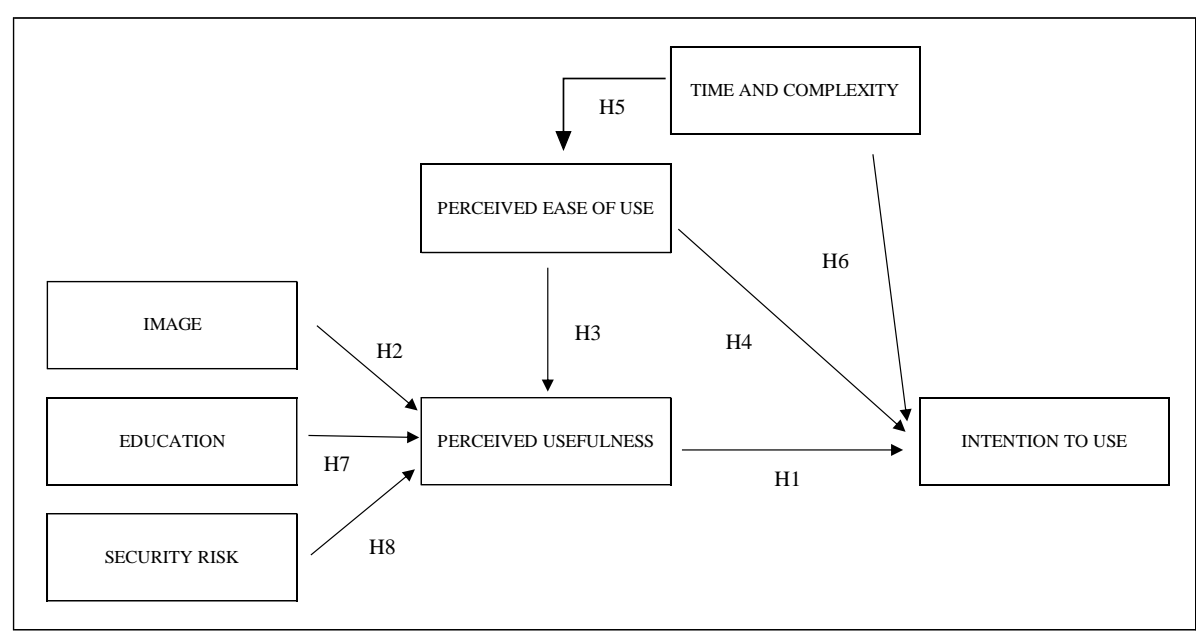

Figure 1 Proposed research model

\section{RESEARCH METHODOLOGY}

The purpose of the study is to investigate cloud computing acceptance by certified auditors and auditors' assistants in the Republic of Croatia. The research question is to investigate which of the proposed variables (and to what extent) affect their intention to accept cloud computing. In order to test the proposed research model for cloud computing acceptance, a survey was conducted among certified auditors and auditors' assistants in the Republic of Croatia. According to the data available on the Croatian Ministry of Finance website, a total of 1,000 certified auditors have been registered in Republic of Croatia /28/. A total of 999 certified auditors were registered in the register available on the website of the Croatian Chamber of Auditors, and active (462) and inactive auditors (537) were clearly distinguished $/ \mathbf{2 9} /$. The number of audit assistants has not been recorded. The target population of the research are certified auditors and auditors' assistants who work in audit firms and are actively engaged in auditing financial statements. The survey was conducted using the questionnaire shown in Table 1. The questionnaire was created in the Google Forms application. The questionnaire was sent in September 2019, using the Mailchimp application to 462 e-mail addresses of certified auditors with a request to forward the questionnaire to their assistants.

A total of 137 survey questionnaires were returned. The structure of the respondents is 111 certified auditors, 26 assistant auditors, of which 87 are women and 50 are men.

A Likert scale was used to measure the attitude of the respondents. The agreement with statements used in the questionnaire were measured using 7-point ordinal scale (1 completely disagree, 7 completely agree). The statements were adopted from previous research.

Table 1 Survey questionnaire items

\begin{tabular}{|c|c|l|c|}
\hline \multicolumn{2}{|c|}{ Construct } & \multicolumn{1}{c|}{ Item } & Source \\
\hline $\begin{array}{c}\text { Perceived } \\
\text { usefulness }\end{array}$ & PU & $\begin{array}{l}\text { Using cloud computing in auditing increases my effectiveness at } \\
\text { work. } \\
\text { I find cloud computing to be useful in my job. } \\
\text { Using cloud computing in auditing improves my performance in } \\
\text { my job. } \\
\text { Using cloud computing would make my job easier. }\end{array}$ & /11/ \\
\hline
\end{tabular}




\begin{tabular}{|c|c|c|c|}
\hline Image & $\mathrm{IM}$ & $\begin{array}{l}\text { Colleagues who use cloud computing are more important than } \\
\text { those who do not use it. } \\
\text { The use of cloud computing in my organization is a status symbol. } \\
\text { Colleagues in my organization who use cloud computing have } \\
\text { more prestige than those who do not. }\end{array}$ & $\begin{array}{l}/ 11 /, \\
/ 13 /\end{array}$ \\
\hline $\begin{array}{l}\text { Perceived } \\
\text { ease of use }\end{array}$ & PEU & $\begin{array}{l}\text { I find cloud computing to be easy to use. } \\
\text { Using cloud computing will be easy to learn. } \\
\text { Cloud computing will be easy to manage. } \\
\text { The use of cloud computing does not require a lot of my mental ef- } \\
\text { fort. }\end{array}$ & /11/ \\
\hline $\begin{array}{l}\text { Time and } \\
\text { complexity }\end{array}$ & $\mathrm{TC}$ & $\begin{array}{l}\text { The use of cloud computing is very complicated, it is difficult to } \\
\text { understand how it is used. } \\
\text { It takes too long to learn how to use cloud computing to pay off us- } \\
\text { ing it. } \\
\text { Using cloud computing takes too much time in completing my } \\
\text { usual business tasks. }\end{array}$ & $/ 15 /, / 8 /$ \\
\hline Education & ED & $\begin{array}{l}\text { My level of understanding of cloud computing was substantially } \\
\text { improved after going through the training program on cloud com- } \\
\text { puting. } \\
\text { My company provided me with complete training in using cloud } \\
\text { computing, that made my use of cloud computing easier. }\end{array}$ & $/ 5 /$ \\
\hline $\begin{array}{c}\text { Security } \\
\text { Risk }\end{array}$ & SR & $\begin{array}{l}\text { I think using cloud computing in auditing has potential security } \\
\text { risks. } \\
\text { I think using cloud computing my data is not protected from mis- } \\
\text { use. } \\
\text { I believe that using cloud computing anyone can see my infor- } \\
\text { mation despite the confidentiality agreements with cloud compu- } \\
\text { ting. } \\
\text { I believe that by using cloud computing my data is subject to third } \\
\text { party manipulation. }\end{array}$ & $\begin{array}{l}/ 19 \\
/ 22 /\end{array}$ \\
\hline $\begin{array}{c}\text { Intention to } \\
\text { use }\end{array}$ & IU & $\begin{array}{l}\text { Overall, I think that using cloud computing services is advanta- } \\
\text { geous. } \\
\text { Overall, I think I would use cloud computing every day in my job. } \\
\text { Assuming I had access to a cloud computing service I would use it. } \\
\text { Since I have access to a cloud computing service, I plan to use it. }\end{array}$ & /11/ \\
\hline
\end{tabular}

Data collected from the survey will be analyzed through several statistical methods by using statistical packages SPSS 23.0 and Amos 11.

In order to verify the proposed model and investigate the relationships between factors in the model, the structural equation model was used. The internal reliability of the measurement model was confirmed by the Cronbach alpha coefficient. All factors are within acceptable limits, ie above the recommended value of $0.7 / 30 /$. Confirmatory factor analysis was performed to test the validity and reliability of the measurement model. The validity of the measurement model includes convergent validity, construct validity, and discriminant validity /31/. The reliability of the construct was measured using the composite reliability coefficient (CR), the desirable coefficient value should be greater than 0.7 . Convergent validity was measured using average extracted variance (AVE) /32/. The AVE value for an individual construct must be 0.5 or greater $/ 31 /$. As can be seen from Table 2, the proposed model meets the criteria. 
Table 2 Internal reliability and convergent validity

\begin{tabular}{|c|c|c|c|c|c|c|}
\hline \multirow[b]{2}{*}{ Construct } & \multirow[b]{2}{*}{ Item } & \multicolumn{3}{|c|}{ Internal reliability } & \multicolumn{2}{|c|}{$\begin{array}{c}\text { Convergent va- } \\
\text { lidity }\end{array}$} \\
\hline & & $\begin{array}{c}\text { Cronbach } \\
\text { alpha }\end{array}$ & $\begin{array}{l}\text { Item- total } \\
\text { correlation }\end{array}$ & $\begin{array}{c}\text { Factor } \\
\text { loading }\end{array}$ & CR & AVE \\
\hline \multirow{4}{*}{ PU } & PU1 & \multirow{4}{*}{0.965} & 0.904 & 0.899 & \multirow{4}{*}{0.937} & \multirow{4}{*}{0.787} \\
\hline & PU2 & & 0.942 & 0.889 & & \\
\hline & PU3 & & 0.915 & 0.888 & & \\
\hline & PU4 & & 0.893 & 0.873 & & \\
\hline \multirow{3}{*}{$\mathrm{IM}$} & IM1 & \multirow{3}{*}{0.920} & 0.840 & 0.905 & \multirow{3}{*}{0.924} & \multirow{3}{*}{0.802} \\
\hline & IM2 & & 0.874 & 0.902 & & \\
\hline & IM3 & & 0.803 & 0.880 & & \\
\hline \multirow{4}{*}{ PEU } & PEU1 & \multirow{4}{*}{0.950} & 0.870 & 0.923 & \multirow{4}{*}{0.944} & \multirow{4}{*}{0.808} \\
\hline & PEU2 & & 0.892 & 0.900 & & \\
\hline & PEU3 & & 0.830 & 0.898 & & \\
\hline & PEU4 & & 0.929 & 0.873 & & \\
\hline \multirow{3}{*}{$\mathrm{TC}$} & TC1 & \multirow{3}{*}{0.917} & 0.781 & 0.925 & \multirow{3}{*}{0.932} & \multirow{3}{*}{0.820} \\
\hline & TC2 & & 0.888 & 0.897 & & \\
\hline & TC3 & & 0.839 & 0.895 & & \\
\hline \multirow{2}{*}{ ED } & ED1 & \multirow{2}{*}{0.917} & 0.847 & 0.879 & \multirow{2}{*}{0.847} & \multirow{2}{*}{0.735} \\
\hline & ED2 & & 0.847 & 0.835 & & \\
\hline \multirow{4}{*}{ SR } & SR1 & \multirow{4}{*}{0.861} & 0.591 & 0.886 & \multirow{4}{*}{0.894} & \multirow{4}{*}{0.679} \\
\hline & SR2 & & 0.749 & 0.842 & & \\
\hline & SR3 & & 0.702 & 0.811 & & \\
\hline & SR4 & & 0.791 & 0.751 & & \\
\hline \multirow{4}{*}{ IU } & IU1 & \multirow{4}{*}{0.952} & 0.916 & 0.911 & \multirow{4}{*}{0.930} & \multirow{4}{*}{0.768} \\
\hline & IU2 & & 0.887 & 0.889 & & \\
\hline & IU3 & & 0.932 & 0.877 & & \\
\hline & IU4 & & 0.843 & 0.827 & & \\
\hline
\end{tabular}

Discriminant validity was tested to confirm that variables within a given factor did not correlate strongly with variables in another factor. To confirm this, the square of the AVE value of each construct must be greater than the correlation of that construct and any other construct /32/. As can be seen from Table 3, the proposed model showed strong discriminant validity.

Table 3 Discriminant validity

\begin{tabular}{|c|r|r|r|r|r|r|r|}
\hline & \multicolumn{1}{|c|}{ PU } & \multicolumn{1}{c|}{ IM } & \multicolumn{1}{c|}{ PEU } & \multicolumn{1}{c|}{ TC } & ED & \multicolumn{1}{c|}{ SR } & \multicolumn{1}{c|}{ IU } \\
\hline PU & 0.887 & & & & & & \\
\hline IM & 0.383 & 0.896 & & & & & \\
\hline PEU & 0.394 & 0.114 & 0.899 & & & & \\
\hline TC & 0.116 & 0.226 & -0.211 & 0.906 & & & \\
\hline ED & 0.44 & 0.294 & 0.313 & -0.059 & 0.857 & & \\
\hline SR & -0.259 & 0.046 & 0.149 & -0.024 & 0.082 & 0.824 & \\
\hline IU & 0.711 & 0.178 & 0.297 & -0.115 & 0.483 & -0.236 & 0.877 \\
\hline
\end{tabular}

\section{RESULTS AND DISCUSSION}


In Table 4 descriptive statistics for all measured variables are showed.

Table 4 Descriptive statistics

\begin{tabular}{|l|r|r|}
\hline $\begin{array}{c}\text { Con- } \\
\text { struct }\end{array}$ & \multicolumn{1}{c|}{ Mean } & $\begin{array}{c}\text { Standard } \\
\text { deviation }\end{array}$ \\
\hline PU & 20.664 & 6.4218 \\
\hline IM & 8.934 & 5.2429 \\
\hline PEU & 21.971 & 5.1762 \\
\hline TC & 7.737 & 4.6245 \\
\hline ED & 9.606 & 3.8317 \\
\hline SR & 17.482 & 6.0623 \\
\hline IU & 23.08 & 5.4692 \\
\hline
\end{tabular}

In order to ensure the model goodness of fit structural equation modeling was applied and different fit indices were used. The goodness of fit index is 0.84 which is slightly lower than rec- ommended but the reason is that it is quite sensitive in small samples /33/. All other indices indicate the good fit of the tested model, as can be seen in Table 5.

Table 5 Model fit indices

\begin{tabular}{|l|c|c|c|}
\hline \multicolumn{1}{|c|}{ Fit index } & Research model & Recommended value & \\
\hline $\mathrm{x}^{2} /$ d.f. & 1.548 & $<5.00$ & {$[34]$} \\
\hline GFI & 0.840 & $>0.90$ & {$[35]$} \\
\hline RMSEA & 0.063 & $<0.08$ & {$[36]$} \\
\hline NFI & 0.903 & $>0.90$ & {$[37]$} \\
\hline CFI & 0.963 & $>0.90$ & {$[38]$} \\
\hline IFI & 0.963 & $>0.90$ & {$[39]$} \\
\hline TLI & 0.954 & $>0.91$ & {$[37]$} \\
\hline
\end{tabular}

After confirming the goodness of fit of the model and the validity and reliability of the measuring instrument, a path analysis of the proposed model was performed to investigate the relationships between the individual constructs and to test the hypotheses. Figure 2 shows the proposed model and the links between the construct. Table 6 shows the results of hypothesis testing.

Table 6 Results of hypothesis testing

\begin{tabular}{|l|l|c|c|c|c|c|}
\hline \multicolumn{2}{|c|}{ Hypothesis } & $\begin{array}{c}\text { Standardized } \\
\text { coefficient }\end{array}$ & SE & CR & p-value & Supported \\
\hline H1 & PU $\rightarrow \mathrm{IU}$ & 0.772 & 0.101 & 7.640 & $* * *$ & Yes \\
\hline H2 & IM $\rightarrow$ PU & 0.271 & 0.081 & 3.352 & $* * *$ & Yes \\
\hline H3 & PEU $\rightarrow$ PU & 0.630 & 0.165 & 3.814 & $* * *$ & Yes \\
\hline H4 & PEU $\rightarrow \mathrm{IU}$ & 0.207 & 0.174 & 1.192 & 0.233 & No \\
\hline H5 & TC $\rightarrow$ PEU & -0.830 & 0.368 & -2.257 & 0.024 & Yes \\
\hline H6 & TC $\rightarrow$ IU & -0.512 & 0.182 & -2.818 & 0.005 & Yes \\
\hline H7 & ED $\rightarrow$ PU & 0.189 & 0.065 & 2.919 & 0.004 & Yes \\
\hline H8 & SR $\rightarrow$ PU & -0.41 & 0.084 & -4.85 & $* * *$ & Yes \\
\hline
\end{tabular}




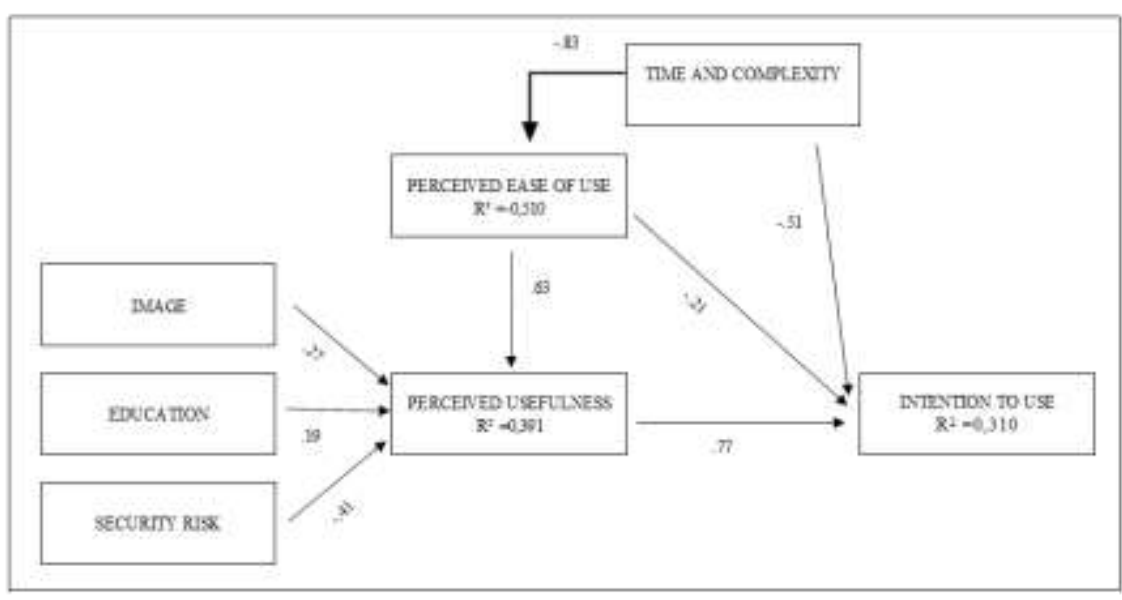

Figure 2 Results of hypothesis tests

As can be seen from Table 6, the study results show that 1 of the 8 hypotheses is rejected while 7 hypotheses are accepted. The effect of perceived ease of use on intention to use was not confirmed (H4, $\beta=0.207, \mathrm{CR}=1.192, \mathrm{p}>0.05)$. A positive effect of perceived usefulness on intention to use was confirmed $(\mathrm{H} 1, \beta=0.772 \mathrm{CR}=$ $7.640, \mathrm{p}<0.01)$ as well as a positive influence of image on perceived usefulness $(\mathrm{H} 2, \beta=0.271$ $\mathrm{CR}=3.352, \mathrm{p}<0.01$ ). The positive impact of perceived ease of use on perceived usefulness $(\mathrm{H} 3$, $\beta=0.630 \mathrm{CR}=3.814, \mathrm{p}<0.01$ ) was also confirmed, as was the positive impact of education on perceived usefulness $(\mathrm{H} 7, \beta=0.189 \mathrm{CR}=$ $2.919, \mathrm{p}<0.01)$. The negative impact of time and complexity on perceived ease of use (H5, $\beta=$ $-0.830 \mathrm{CR}=-2.257, \mathrm{p}<0.05)$ and its negative effect on intention to use (H6, $\beta=-0.512 \mathrm{CR}=$ $-2.818, \mathrm{p}<0.01)$. The negative impact of safety risk on perceived usefulness was also confirmed (H8, $\beta=-0.41 \mathrm{CR}=-4.85, \mathrm{p}<0.01)$. The intention to use cloud computing through the proposed model explains a total of $31 \%\left(R^{2}=\right.$ 0.310 ) of the variance in cloud computing acceptance.

\section{SOME CONCLUDING REMARKS}

The aim of the study was to assess the validity of the proposed model for measuring cloud computing acceptance by auditors and auditors' assistants. The model showed that the intention to use cloud computing was positively influenced by perceived usefulness and negatively affected by time and complexity, while the direct impact of perceived ease of use on the intention to use was not significant. Perceived ISSN 1330-0067 usefulness is influenced by image, education, security risk and perceived ease of use. Security risk negatively affects perceived usefulness while image, education, and perceived ease of use have a positive effect. This means that if the use of cloud computing would add to the individual's reputation and status, he would use it, as well as in the case of some training and education, and when the use of cloud computing would be perceived as easily manageable. As a negative impact on perceived usefulness, individuals' concerns about the security and privacy of data in cloud computing have been confirmed. The results obtained are consistent with previous research by Alshamail regarding the impact of complexity on the intention to use /8/. The impact of security risk has also been confirmed in line with Park and Kim and Lee's research $/ 20 /, / 22 /$.

The results of the research contribute to a better understanding of the factors that influence cloud computing acceptance but also indicate the limitations of this research, which shows that the model explains only $31 \%$ of the variance of intended use of cloud computing or cloud computing adoption, $39 \%$ of the variance of perceived usefulness and $51 \%$ of the variance of perceived ease of use. This means that further research should be geared toward exploring variables that affect cloud computing acceptance, such as expected performance impact, expected effort and social impact, behavioural intention, and conditions of use /4/. The limitation of the survey is the sample size, ie the number of questionnaires returned.

Coden: IORME7 
Notes

/1/ Marston S., Li Z., Bandyopadhyay S., Zhang J., Ghalsasi A. (2011), "Cloud computing - The business perspective," Decision Support Systems, pp. 176-189, 4

/2/ CARNet, "Centar informacijske sigurnosti," (2010), [Online]. Available: https://www.cis.hr/www.edicija/LinkedDocume nts/NCERT-PUBDOC-2010-03-293.pdf.

/3/ Alharbi S. (2017), “An extended UTAUT model for understanding of the effect of trust on users acceptance of cloud computing," International Journal of Computer Applications in Technology Vol.56. No.1., pp. 65-76.

/4/ Venkatesh V., Morris M. G., Davis G. B., Davis F. D. (2003), "User Acceptance of Information Technology: Toward a Unified View," MIS Quarterly, pp. 425-478, September

/5/ Gangwar H., Date H., Ramaswamy R. (2013), "Understanding determinants of cloud computing adoption using an integrated TAMTOE model," Journal of Enterprise Information Management, pp. 107-130.

/6/ Wang Y.-M., Wang Y.-S., Yangb Y.-F. (2010), "Understanding the determinants of RFID adoption in the manufacturing industry," Technological Forecasting and Social Change, Volume 77, Issue 5, pp. 803-815.

/7/ Riyadh A. N., Akter S., Islam N. (2009), “The adoption of e-banking in developing countries: A theoretical model for SMEs," International Review of Business Readearch Papers, Vol. 5, No. 6, pp. 212230.

/8/ Alshamaila Y., Papagiannidis S., Li F. (2013), "Cloud computing adoption by SMEs in the north east of England A multi-perspective framework," Journal of Enterprise Information Management, pp. 250.

19/ Davis F., Bagozzi R., Warshaw P. (1989), “User acceptance of computer technology: A comparison of two theoratical models," Management science, pp. 982-1003.

/10/ Vasarhelyi M. A., Romero S. (2014), “Technology in audit engagements: a case study," Managerial Auditing Journal, pp. 350-365.

/11/ Venkatesh V., Davis F. D. (2000), “A Theoretical Extension of the Technology Acceptance Model: Four Longitudinal Feld Studies," Management Science, pp. 186-204.

/12/ Chuttur M. (2009), “Overview of the Technology Acceptance Model: Origins, Developments and Future Directions," Sprouts: Working Papers on Information Systems, pp. 9-37.

/13/ Venkatesh V., Bala H. (2008), “Technology Acceptance Model 3 and a Resarch Agenda on Interventions," Decision Sciences, pp. 273-315.
/14/ Tornatsky L., Fleischer M. (1990), The Process of Technology Innovation, Lexington, MA: Lexington Books

/15/ Okcu S., Hancerliogullari K. G., Basak E., Calisir F. (2019), "Factors Affecting Intention to Use Big Data Tools: An Extended Technology Acceptance Model," Industrial Engineering in the Big Data Era, pp. 401-416.

/16/ Rogers E. M., Shoemaker F. F. (1971), Communication of innovations: A cross-cultural approach, Free Press

/17/ Wheeler B. C., Valacich J. S. (1996), “Facilitation, GSS, and Training as Sources of Process Restrictiveness and Guidance for Structured Group Decision Making: An Empirical Assessment," Information Systems Research, pp. 429-450.

/18/ Venkatesh V., Speier C.(1999), “Computer Technology Training in the Workplace: A Longitudinal Investigation of the Effect of Mood.," Organ Behav Hum Decis Process, pp. 128.

/19/ Wu J.-H., Wang S.-C. (2005), “What drives mobile commerce?: An empirical evaluation of the revised technology acceptance model," Information \& Management, pp. 719-729.

/20/ Lee Y.-C. (2017), “Adoption Intention of Cloud Computing at the Firm Level," Journal of Computer Information Systems, pp. 61-72.

/21/ Khansa L., Zobel C. (2014), “Assessing innovations in cloud security," Journal of Computer Information Systems 54(3), pp. 45-56.

/22/ Park E., Kim K. J. (2014), “An Integrated Adoption Model of Mobile Cloud Services: Exploration of Key Determinants and Extension of Technology Acceptance Model," Telematics and Informatics, pp. 376-385.

/23/ Curtis M. B., Payne E. A. (2008), “An examination of contextual factors and individual characteristics affecting technology implementation decisions in auditing," International Journal of Accounting Information Systems, Vol.9 Issue 2, pp. 104-121.

/24/ Rastogi G., Verma H., Sushil R. (2018), "Determining Factors Influencing Cloud Services Adoption in India," Serbian Journal of Management, pp. 335-352.

/25/ Mathieson K. (1991), “Predicting User Intentions: Comparing the Technology Acceptance Model with the Theory of Planned Behavior," Information Systems Research 2(3), pp. 173-191.

/26/ Ajzen I., Fishbein M. (1980), Understanding Attitudes and Predicting Social Behavior

/27/ Andenmatten M., Hollwarth T. (2016), "Euroclaud," [Online]. Available: https://www.google.com/url?sa=t\&source=we 
b\&rct=j\&url=https://assets.kpmg/content/dam/ $\mathrm{kpmg} / \mathrm{ch} / \mathrm{pdf} /$ the-power-of-thecloud.pdf\&ved=2ahUKEwjFudX5y8nkAhUm AxAIHXEvBSoQFjACegQIARAB\&usg=AOvV aw2ngOD3m_p7zJSXJTA6SYsB.

/28/ "RH Ministarstvo financija," (2020). [Online]. Available: https://mfin.gov.hr/istaknuteteme/revizija/registri/434.

/29/ "Hrvatska revizorska komora," (2020.) [Online]. Available: http://www.revizorskakomora.hr/index.php/registri/pretraga.html.

/30/ Field A. (2013), Discovering statistics using IBM SPSS Statistics, London: SAGE Publications Ltd., 2013.

/31/ Ahmad S., Zulkurnain N., Khairushalimi F. (2016), "Assessing the Validity and Reliability of a Measurement Model in Structural Equation Modeling (SEM)," British Journal of Mathematics and Computer Science, pp. 1-8.

/32/ Hair J. Jr, Black W., Babin B., Anderson R. (2010), Multivariate Data Analysis 7th EDITION, New Delhi: Pearson, India

/33/ Marsh H., Balla J. R., McDonald R. P. (1988), "Goodness-of-Fit Indexes in Confirmatory Factor Analysis: The Effect of Sample Size," Psychological Bulletin 103(3), pp. 391-411.
/34/ Bentler P. (2007), “On tests and indices for evaluating structural models," Personality and Individual Differences, pp. 825-829.

/35/ Bagozzi R. P., Yi Y. (1988), “On the Evaluation of Structure Equation Models," Journal of the Academy of Marketing Science 16(1), pp. 74-94.

/36/ Marsh H., Hocevar D. (1985), “Application of confirmatory factor analysis to the study of selfconcept: First- and higher order factor models and their invariance across groups.," Psychological Bulletin, pp. 562-582.

/37/ Bentler P. M., Bonnet D. G. (1980), “Significance tests and goodness of fit in the analysis of covariance structures," Psychological Bulletin, pp. 588-606.

/38/ Hu L., Bentler P. (1999), “Cutoff criteria for fit indexes in covariance structure analysis:," [Online].

/39/ Widaman K. F., Thompson J. S. (2003), “On specifying the null model for incremental fit indices in structural equation modeling," Psychol Bulletin 88, pp. 16-37.

/40/ Tornatsky L. a. F. M. (1990), The Process of Technology Innovation, Lexington, MA: Lexington Books 